\title{
Effect of Humidity in Air on Performance and Long-Term Durability of SOFCs
}

\author{
Hagen, Anke; Neufeld, Kai; Liu, Yi-Lin
}

Published in:

Journal of The Electrochemical Society

Link to article, DOI:

$10.1149 / 1.3459904$

Publication date:

2010

Document Version

Publisher's PDF, also known as Version of record

Link back to DTU Orbit

Citation (APA):

Hagen, A., Neufeld, K., \& Liu, Y-L. (2010). Effect of Humidity in Air on Performance and Long-Term Durability of SOFCs. Journal of The Electrochemical Society, 157(10), B1343-B1348. https://doi.org/10.1149/1.3459904

\section{General rights}

Copyright and moral rights for the publications made accessible in the public portal are retained by the authors and/or other copyright owners and it is a condition of accessing publications that users recognise and abide by the legal requirements associated with these rights.

- Users may download and print one copy of any publication from the public portal for the purpose of private study or research.

- You may not further distribute the material or use it for any profit-making activity or commercial gain

- You may freely distribute the URL identifying the publication in the public portal

If you believe that this document breaches copyright please contact us providing details, and we will remove access to the work immediately and investigate your claim. 


\title{
Effect of Humidity in Air on Performance and Long-Term Durability of SOFCs
}

\author{
A. Hagen, ${ }^{\mathrm{z}}$ K. Neufeld, and Y. L. Liu
}

Risф Technical University of Denmark, National Laboratory for Sustainable Energy, DK-4000 Roskilde, Denmark

\begin{abstract}
Anode-supported solid oxide fuel cells (SOFCs) based on Ni-yttria-stabilized zirconia (YSZ) anodes, YSZ electrolytes, an lanthanum strontium manganite (LSM)-YSZ cathodes were studied with respect to durability in humid air $(\sim 4 \%)$ typically over $1500 \mathrm{~h}$. Operating temperature and current density were varied between 750 and $850^{\circ} \mathrm{C}$ and $0.25-0.75 \mathrm{~A} / \mathrm{cm}^{2}$, respectively. The introduction of humidity affected the cell voltage under polarization of the cell, and this effect was (at least partly) reversible upon switching off the humidity. Generally, the studied cells were operated in humid air under technologically relevant conditions over more than $1500 \mathrm{~h}$. Improvements at the cathode/electrolyte interface made it possible to obtain highly stable cells, which can be operated under high current density and at $750^{\circ} \mathrm{C}$ in humid air, conditions that cause significant cell voltage degradation in dry air on cells with LSM/YSZ-based cathodes.
\end{abstract}

(c) 2010 The Electrochemical Society. [DOI: 10.1149/1.3459904] All rights reserved.

Manuscript submitted February 16, 2010; revised manuscript received May 21, 2010. Published July 27, 2010. This was Paper

1320 presented at the Vienna, Austria, Meeting of the Society, October 4-9, 2009.

Performance, durability, and cost are crucial aspects for the success of solid oxide fuel cell (SOFC) technology. A detailed study of the initial performance and degradation mechanisms under relevant operating conditions and at different levels, from materials to stacks and systems, is required to develop a competitive SOFC technology.

Approaching the market, it becomes more and more important to address the durability of SOFCs under realistic operating conditions also comprising impurities in the supplied gasses, such as sulfur compounds in the fuel or humidity in air.

Ambient air always contains certain degrees of humidity depending on location and climate. A thorough knowledge of its effects on initial performance and long-term durability is required if drying units in the SOFC systems are to be avoided. Fundamental studies on yttria-stabilized zirconia (YSZ) were conducted using oxygen isotopes and applying small degrees of humidification. ${ }^{1}$ An enhancement of the surface reaction rate was observed under humid conditions. This result leaves the question on how this enhancement is reflected in the performance of a full cell, i.e., including the action of the cathode layer and the real situation at the cathode/electrolyte interface. Kim et al. ${ }^{2}$ studied the effect of humidity in air on the performance of an SOFC with an lanthanum strontium manganite (LSM)/scandia stabilized zirconia cathode during short-term exposure. A cell voltage drop was observed when introducing larger degrees of humidity (20 and 40 vol \%), while the cell voltage increased slightly at 3 vol $\%$ humidity at $800^{\circ} \mathrm{C}$. The voltage drop was related to $\mathrm{La}_{2} \mathrm{O}_{3}$ particles segregated to the LSM surface, as observed by scanning electron microscopy (SEM). ${ }^{2}$ The durability over longer times than a few hours at most realistic degrees of humidity was not addressed.

In a complementary study, SOFCs with LSM/YSZ cathodes were exposed to humid air of different degrees and at different current loads/polarizations over periods of a few hundred hours. ${ }^{3}$ In addition to the already mentioned voltage drop when starting the humidification of air, an increased cell voltage degradation was observed during exposure of humidity. Both the cell voltage drop and cell voltage degradation increased with increasing humidification degree under polarization. A postmortem microstructural analysis of a cell quenched at a high degree of humidity revealed nanoparticles around the LSM/YSZ cathode/YSZ electrolyte interface, which might be responsible for the larger cell voltage degradation. Humid air has also been considered previously in relation to interconnects and Cr-poisoning phenomena.

In this study, a comprehensive testing program on SOFCs with LSM/YSZ cathodes was accomplished, where the cells were oper-

${ }^{\mathrm{z}}$ E-mail: anke.hagen@ risoe.dk ated over periods between 500 and $2500 \mathrm{~h}$ in the presence of $\sim 4 \%$ humidity in air. The parameters current density and temperature were varied. The testing comprised two different versions of LSM/ YSZ cathodes in anode-supported SOFCs, and the results were compared to corresponding durability tests typically over $1500 \mathrm{~h}$ in dry air. The study furthermore comprised a microstructural analysis of the tested and reference cells as well. The aim was to achieve a better understanding of the long-term processes under humid air conditions and their correlation with polarization and cathode microstructural properties.

\section{Experimental}

SOFCs. - Anode-supported SOFCs manufactured in the prepilot laboratory located at Ris $\emptyset$ DTU were used. These cells were based on a supporting and active Ni-YSZ cermet anode, a YSZ electrolyte, and an LSM-YSZ composite cathode. The active area was $4 \mathrm{~cm}$ $\times 4 \mathrm{~cm}$ (Ref. 7). For the so-called standard cells, the layers were deposited by tape casting the anode support and spraying the anode, electrolyte, and cathode. The same half-cells were used in another cell series, where the LSM-YSZ cathode was deposited by a screen printing process.

Testing equipment.- The electrochemical and aging tests were performed in alumina test houses placed in furnaces and equipped with current and voltage probes, thermocouples, and gas lines. $p_{\mathrm{O}_{2}}$ sensors were placed at the fuel inlet and outlet tubes to measure the fuel composition. The cells were sandwiched between ceramic gas distribution layers (Ni-containing on the anode and LSM-containing at the cathode side, respectively) and current collectors (nickel and gold foils at the anode and cathode side, respectively). The test setup and method were described in detail in Ref. 8.

Testing protocol. - The cells were first sealed and reduced at $1000^{\circ} \mathrm{C}$. Afterward, the temperature was lowered to start the initial electrochemical characterization at 850,800 , and $750^{\circ} \mathrm{C}(i-V$ curves and impedance spectra: Solartron SI 1260 impedance analyzer in 4 and $20 \%$ humidified hydrogen). The same characterization was also performed after completion of the aging tests. Long-term testing was carried out at 850,800 , and $750^{\circ} \mathrm{C}$ and different constant current loads. The fuel gas was a mixture of $\mathrm{CO}_{2}$ and hydrogen with a ratio of 1:4, yielding an equilibrium mixture of $\mathrm{CO}: \mathrm{H}_{2}: \mathrm{H}_{2} \mathrm{O}=1: 4: 1$. The fuel utilization was adjusted to lie between 75 and $85 \%$ (typically, $1 \mathrm{~L} / \mathrm{h} \mathrm{CO}_{2}+4 \mathrm{~L} / \mathrm{h} \mathrm{H}_{2}$ ). Air was used as cathode gas, both dry and humidified. Dry air contained $\leq 0.1 \% \quad \mathrm{H}_{2} \mathrm{O}$. The humidification was accomplished by leading air through a water flask at room temperature, yielding a degree of humidification of ca. $4 \%$. The typical air utilization (if not stated otherwise) was $10 \%(140 \mathrm{~L} / \mathrm{h}$ air). 


\begin{tabular}{|c|c|c|c|c|}
\hline \multirow[b]{2}{*}{ Test ID } & \multirow{2}{*}{$\frac{\text { Initial characterization }}{\mathrm{ASR}_{\text {ini }} \text { at } 850^{\circ} \mathrm{C}}$} & \multicolumn{3}{|c|}{ Aging conditions } \\
\hline & & $\begin{array}{l}T_{\text {aging }} \\
\left({ }^{\circ} \mathrm{C}\right)\end{array}$ & $\begin{array}{c}\% \mathrm{H}_{2} \mathrm{O} \\
\text { on cathode }\end{array}$ & $\begin{array}{c}i \\
\left(\mathrm{~A} / \mathrm{cm}^{2}\right)\end{array}$ \\
\hline 2 test 46 & 0.16 & 750 & $\sim 4$ & 0.25 \\
\hline 12 test 32 & 0.19 & 750 & $\sim 4$ & 0.41 \\
\hline 2 test 50 & 0.20 & 750 & $\sim 4$ & 0.75 \\
\hline 12 test 33 & 0.16 & 750 & $\sim 4$ & 0.75 \\
\hline 13 test $57^{\mathrm{b}}$ & 0.15 & 750 & $\sim 4$ & 0.5 \\
\hline 5test34 & 0.21 & 800 & $\sim 4$ & 0.5 \\
\hline 2 test 47 & 0.20 & 850 & $\sim 4$ & 0.25 \\
\hline 12 test $35^{\mathrm{c}}$ & 0.21 & 750 & $\sim 4$ & 0.5 \\
\hline 14test7 & 0.22 & 750 & $<0.1$ & 0.25 \\
\hline 12 test 8 & 0.25 & 750 & $<0.1$ & 0.41 \\
\hline 13 test5 & 0.17 & 750 & $<0.1$ & 0.75 \\
\hline 2 test 16 & 0.19 & 750 & $<0.1$ & 0.75 \\
\hline 4test 22 & 0.18 & 750 & $<0.1$ & 0.75 \\
\hline 12 test 29 & 0.22 & 750 & $<0.1$ & 0.75 \\
\hline \multicolumn{5}{|c|}{ Average: $0.19 \pm 0.03$} \\
\hline $\begin{array}{l}\text { a Determine } \\
{ }^{\mathrm{b}} \text { The air u } \\
\text { before thi } \\
{ }^{\mathrm{c}} \text { Cell with } \\
\text { aging peri } \\
\text { for } 23001\end{array}$ & $\begin{array}{l}\text { from } i-V \text { curves and cor } \\
\text { ization was } 50 \% \text { during } \\
\text { geriod, the cell had been } \\
\text { timized cathode: the air } \\
\text { in humid air; before thi } \\
\text { n dry air. }\end{array}$ & $\begin{array}{l}\text { cted fo } \\
\text { ee agin } \\
\text { sted fo } \\
\text { tilizatic } \\
\text { eriod, }\end{array}$ & $\begin{array}{l}\text { uel utilizatio } \\
\text { period in hu } \\
1800 \mathrm{~h} \text { in dry } \\
\text { was } 70 \% \text { du } \\
\text { cell had bee }\end{array}$ & $\begin{array}{l}\text { id air; } \\
\text { air. } \\
\text { ng the } \\
\text { tested }\end{array}$ \\
\hline
\end{tabular}

Microstructural analysis.-For the microstructural analysis of the cathode/electrolyte interface, a field emission gun-SEM Supra-35 was used (sample not coated, accelerating voltage of $2 \mathrm{kV}$, secondary detector). The cathode layer was removed by treating the cell in concentrated hydrochloric acid in an ultrasonic bath at room temperature for a few minutes. Subsequently, the sample was cleaned in water and ethanol. YSZ and $\mathrm{La}_{2} \mathrm{Zr}_{2} \mathrm{O}_{7}$ are stable in $\mathrm{HCl}$ whereas LSM is dissolved. To identify possible reaction products in the interface region, various energy-dispersive spectroscopy (EDS) techniques (point analysis and linescan) were applied.

\section{Results and Discussion}

Initial electrochemical characterization.- The purpose of the initial characterization was to ensure that all cells to be tested for durability are performing equally in an acceptable range. In Table I, the initially measured area specific resistance (ASR) values are listed for the cells to be tested in dry or humid air. There was a certain variation in the initial performance of $0.19 \pm 0.03 \Omega \mathrm{cm}^{2}$. One has to keep this variation in mind when evaluating cell voltage degradation rates and small differences in those.

General observations. - In the current study, aging tests of 1500 $\mathrm{h}$ were performed at three temperatures and at four current densities at $750^{\circ} \mathrm{C}$ to cover ranges dominated by anode or cathode degradation as well. Typically, the aging tests were initiated in dry air, and after a period of $\sim 24$ to $48 \mathrm{~h}$, air was humidified. After additionally $1500 \mathrm{~h}$ (or shorter, depending on the degradation rate), the humidification was stopped and the test completed in dry air, followed by a final electrochemical characterization at open-circuit voltage (OCV).

In Fig. 1, a typical cell voltage behavior is shown for the test at $800^{\circ} \mathrm{C}$ and $0.5 \mathrm{~A} / \mathrm{cm}^{2}$. During the initial period in dried air, the cell voltage decreased slightly in a linear manner. The start of the humidification of air had an immediate effect on the cell voltage; it dropped fast within $\sim 10$ to $20 \mathrm{~h}\left(\Delta U_{\text {start }}\right)$. Afterward, a smaller, linear cell voltage degradation was observed over the next $1500 \mathrm{~h}$. When stopping the humidification and returning to dry air, the cell voltage fastly increased (jump) back to the same or a lower cell

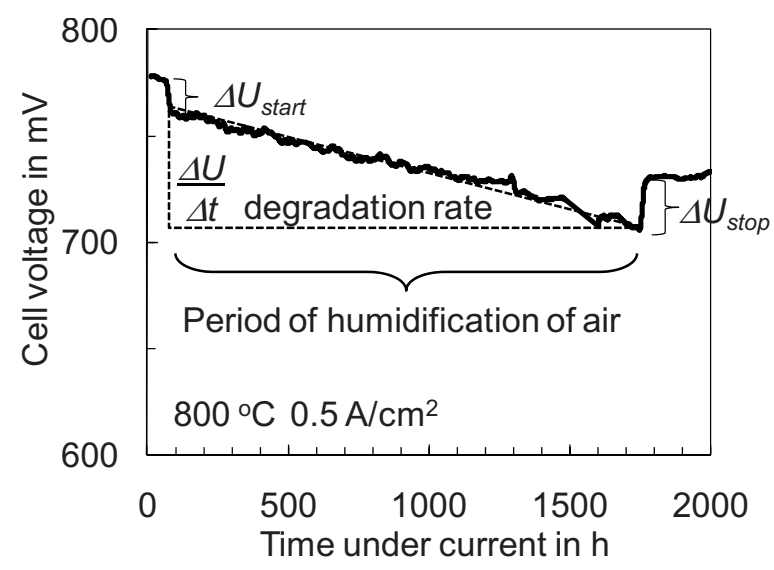

Figure 1. Cell voltage in 5 test $34,800{ }^{\circ} \mathrm{C}, 0.5 \mathrm{~A} / \mathrm{cm}^{2}, 80 \%$ fuel utilization, $10 \%$ air utilization $(140 \mathrm{~L} / \mathrm{h}), 4 \%$ humidity in air during the marked period, illustration of $\Delta U_{\text {start }}$ and $\Delta U_{\text {stop }}$, and calculation of the cell voltage degradation rate.

voltage than the one at the start of the humidification $\left(\Delta U_{\text {stop }}\right)$. The cell voltage remained nearly constant afterward. Thus, humidification of air had an immediate and a long-term effect on the cell voltage, which is discussed in more detail in the following.

Immediate effect of humidification of air. - The immediate changes in the cell voltage were too large to be related to the change in air composition [electromotive force (emf)]. The magnitude of the initial cell voltage drop $\left(\Delta U_{\text {start }}\right)$ and final cell voltage jump $\left(\Delta U_{\text {stop }}\right)$ was therefore evaluated in relation to the applied current density. In Fig. 2, the cell voltage changes were plotted as a function of the cell polarization $\left[\eta_{\text {cell }}(\mathrm{emf}-\mathrm{U})\right]$. Values are listed in Table II. At OCV, the cell voltage did not change when the degree of humidification of the cathode gas was changed from $\sim 0.1$ to $4 \%$. With increasing current density and thus cell polarization, the magnitude of the cell voltage drops (and jumps when returning to try air) increased. The effects of humidity and polarization are thus inter-related.

Impedance spectra were measured under current load to reveal more details of the occurring processes. Examples from three tests are shown in Fig. 3. In the two examples, the air conditions were changed from dried to humidified air (Fig. 3a and b) and in the third example back from humidified to dried air (Fig. 3c).

Comparing the changes occurring during the start of humidification at two operating temperatures $\left(750\right.$ and $\left.800^{\circ} \mathrm{C}\right)$, the increase in resistance was more significant at $750^{\circ} \mathrm{C}$ (see Fig. 3a and b). This is consistent with the observed magnitude of cell voltage drops, which

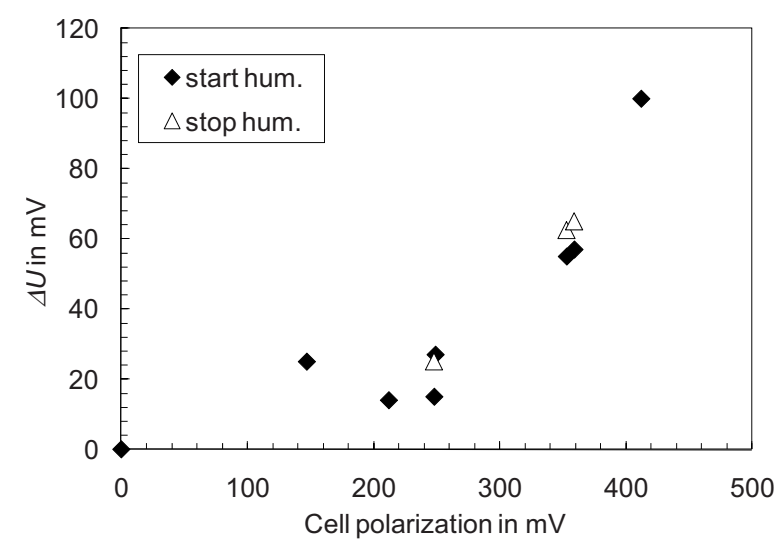

Figure 2. Cell voltage drop ( $\Delta U_{\text {start }}$ : diamonds) and jump ( $\Delta U_{\text {stop: }}$ : triangles) during the start and stop of humidification of cathode air, respectively, as a function of cell polarization. 
a)

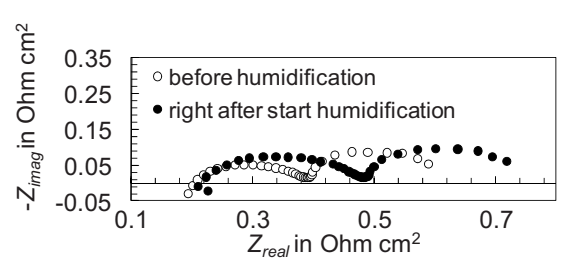

b)

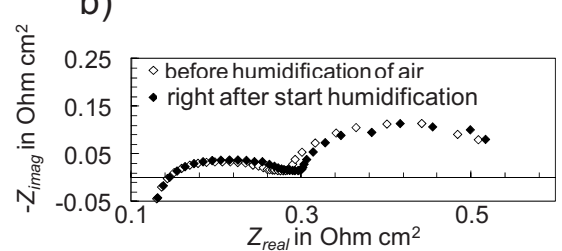

c)

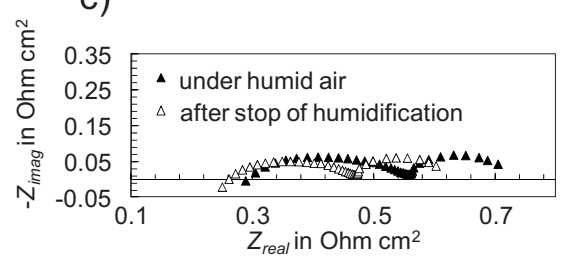

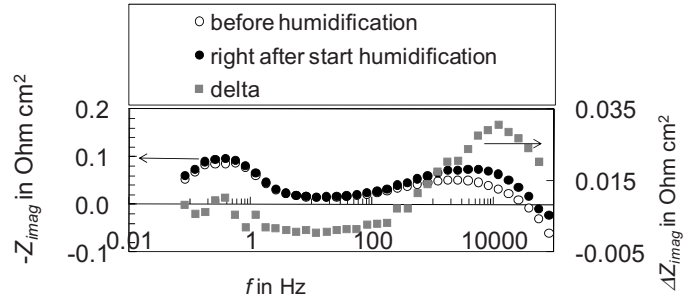
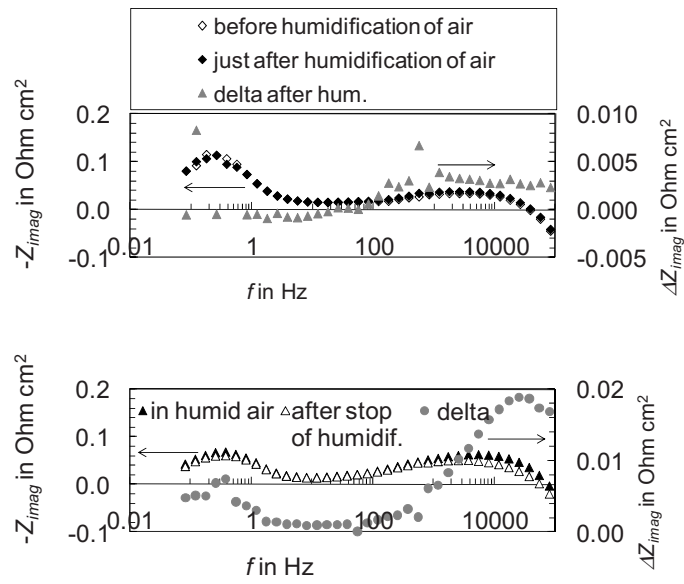

Figure 3. Impedance spectra (Nyquist and $-Z_{\text {imag }}$ vs $f$ plot) recorded under current load, just before the start of the $4 \%$ humidification of air and right after the start at (a) $750^{\circ} \mathrm{C}$ and $0.75 \mathrm{~A} / \mathrm{cm}^{2}$ (2test50), (b) $800^{\circ} \mathrm{C}$ and $0.5 \mathrm{~A} / \mathrm{cm}^{2}$ (5test34), and (c) recorded just before and after stopping humidification of air at $750{ }^{\circ} \mathrm{C}$ and $0.75 \mathrm{~A} / \mathrm{cm}^{2}$ (12test33). Delta in the plots are the differences between the two shown spectra. For test conditions see also Table was smaller for the test at $800^{\circ} \mathrm{C}$ (see Table II). Furthermore, the increase in the total resistance was due to a simultaneous increase in both serial and polarization resistances (see Fig. 3a and b). The frequency region mainly affected by the change in the degree of humidity in air was around $12 \mathrm{kHz}$ for the $750^{\circ} \mathrm{C}$ test (Fig. 3a).

When stopping the humidification of air, the reverse effect was observed. The resistance decreased immediately; the serial and the polarization resistances both decreased (see Fig. 3c). The effect of humidity is thus more complex than merely a "covering" of active areas. Moreover, as the changes in cell voltages were fast (and reversible), the related processes must also be fast and reversible. Comprehensive microstructural changes such as deposition (and removal) of larger particles or formation (and dissolution) of isolating phases seem therefore unlikely to be responsible for the cell voltage drops (and jumps) when starting (or stopping) the humidification of air.

Long-term effect of humidification of air. - Results from previous aging tests in dry air (specifically, cell voltage degradation rates) $)^{9}$ were used as references. In this durability study of typically $1500 \mathrm{~h}$, the cell voltage degradation rates increased with increasing current density/cell polarization, in particular at lower operating temperatures of 750 vs $850^{\circ} \mathrm{C}$. The degradation at $750^{\circ} \mathrm{C}$ was mainly related to cathode processes. ${ }^{9}$

The long-term effect of $\sim 4 \%$ humidity in air was studied for a series of cells usually over $1500 \mathrm{~h}$ at 850,800 , and $750^{\circ} \mathrm{C}$ at different current densities. As a measure of degradation, the linear cell voltage degradation over the whole aging period was determined

\footnotetext{
Table II. Immediate changes in the cell voltages during the start $\left(\Delta U_{\text {start }}\right)$ of the humidification of air.
}

\begin{tabular}{lccc} 
Test ID & $\begin{array}{c}T_{\text {aging }} \\
\left({ }^{\circ} \mathrm{C}\right)\end{array}$ & $\begin{array}{c}i \\
\left(\mathrm{~A} / \mathrm{cm}^{2}\right)\end{array}$ & $\begin{array}{c}\Delta U_{\text {start }} \\
(\mathrm{mV})\end{array}$ \\
\hline 2test46 & 750 & 0.25 & 25 \\
12test32 & 750 & 0.41 & 27 \\
2test50 & 750 & 0.75 & 100 \\
12test33 & 750 & 0.75 & 55 \\
5test34 & 800 & 0.5 & 15 \\
2test47 & 850 & 0.25 & 2
\end{tabular}

(see also Ref. 9 and Fig. 1 for illustration). In Fig. 4, these values are plotted as a function of the cell polarization and are compared to the reference tests in dry air (these data are from the study published in Ref. 9). At a higher operating temperature of $850^{\circ} \mathrm{C}$ and $0.25 \mathrm{~A} / \mathrm{cm}^{2}$, the cell voltage degradation rates were $0 \mathrm{mV} / 1000 \mathrm{~h}$ for the test in dry air and $8 \mathrm{mV} / 1000 \mathrm{~h}$ in humid air (see circle in Fig. 4). The cell voltage was thus hardly affected by the introduction of $\sim 4 \%$ humidification of air.

At $750^{\circ} \mathrm{C}$, the cell voltage degradation rates in humid air were

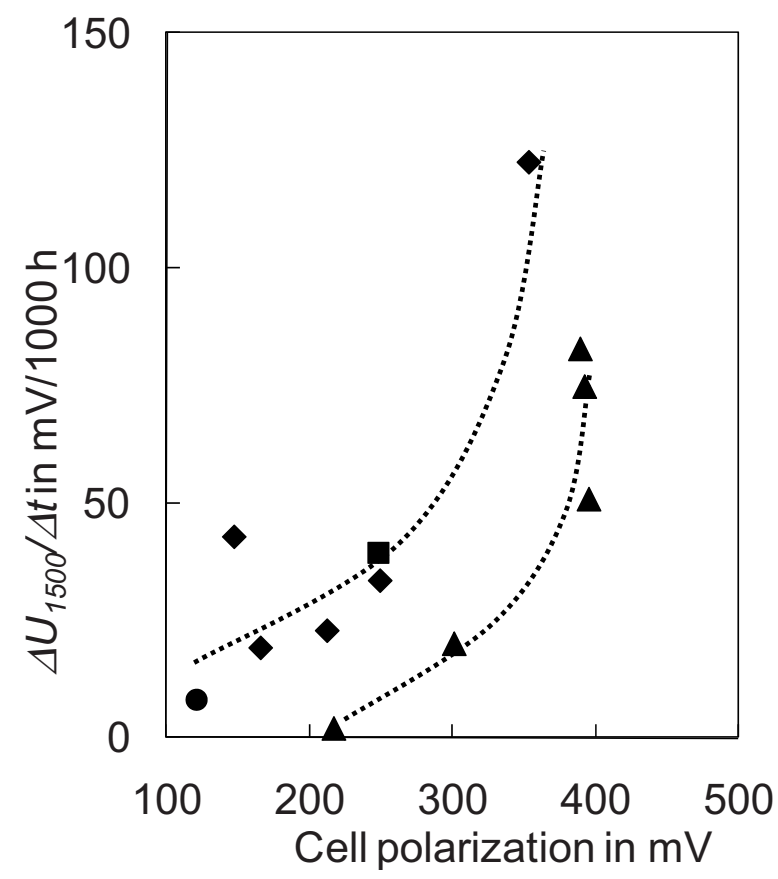

Figure 4. Cell voltage degradation rates during aging tests in dry (triangles: $750^{\circ} \mathrm{C}$, from Ref. 9) or humid air (rhombs: $750^{\circ} \mathrm{C}$, square: $800^{\circ} \mathrm{C}$, and circle: $850^{\circ} \mathrm{C}$ ) determined as linear decrease over the $\sim 1500 \mathrm{~h}$ aging period (in $\mathrm{mV} / 1000 \mathrm{~h}$ ) as a function of cell polarization. 

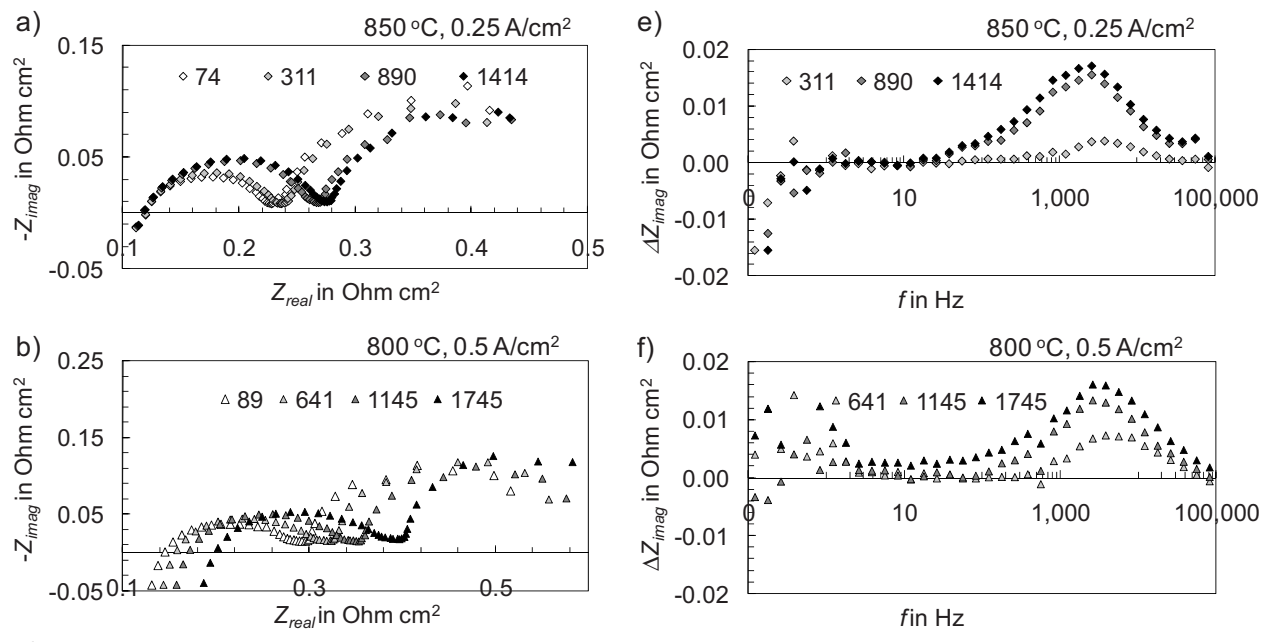

Figure 5. Impedance spectra recorded under current load (a) to (d) during periods with humidified air and changes in imaginary parts in relation to the first recorded impedance $\left(\Delta Z_{\text {imag }}\right)$ vs frequency (e) to (h). The numbers in the figures show the hours in humidified air. [(a) and (e)]
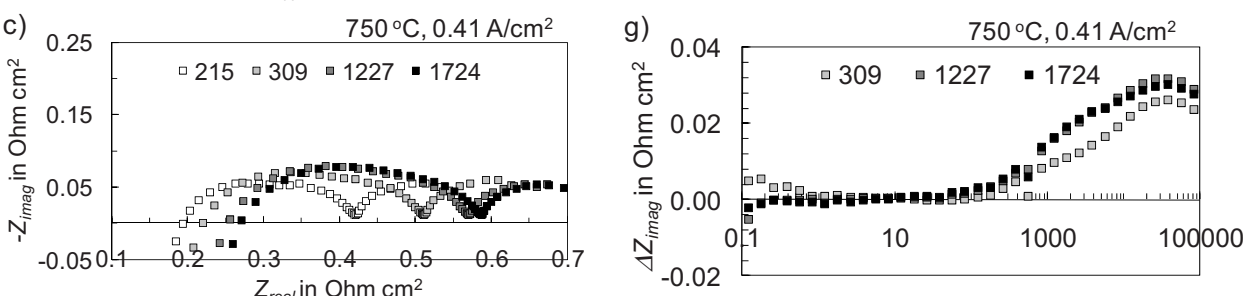
test 47, [(b) and (f)] 5test34, (c) and (g) 12 test 32 , and $[(d)$ and (h)] 12test 33 . For test conditions see numbers in the figure and also in Table I.

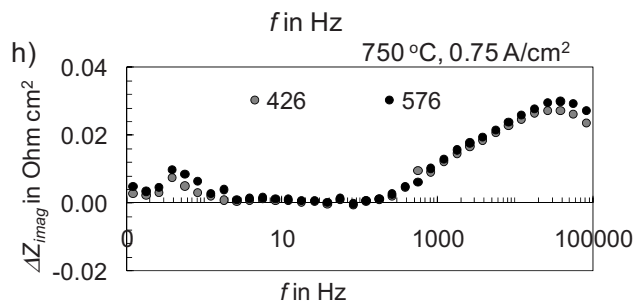

larger compared to the operation in dried air under the same current load/cell polarization. Furthermore, they increased with increasing cell polarization (see Fig. 4). The tests at $800^{\circ} \mathrm{C}$ gave a similar trend as the tests at $750^{\circ} \mathrm{C}$ (square in Fig. 4). Thus, the cell polarization seems to have a larger effect on the cell voltage degradation rate than the temperature in the range between 800 and $750^{\circ} \mathrm{C}$. Furthermore, in humid air, the same general trends of the cell voltage degradation rates as those observed in dried air were obtained as a function of cell polarization.

The effect of humidification of air on the cell voltage degradation was reversible, i.e., the cell voltage recovered after the humidification was stopped (see Fig. 1 as an example and Fig. 2 and Table II for the values). When the test was continued in dried air, the cell voltage degradation rate decreased to a value similar or even smaller to the rate before humidification (see Fig. 1).

The impedance spectra under current load were recorded frequently during the long-term humidification of air. In Fig. 5, a series of representative spectra is shown. Examples from tests at 850, 800, and $750^{\circ} \mathrm{C}$ were chosen and two tests at different current loads at $750^{\circ} \mathrm{C}$. First, the trends with regard to the extent of degradation were consistent between the cell voltage measurements (see Fig. 4) and impedance spectra recorded under current load (Fig. 5). The smallest cell voltage degradation was observed in the test at $850^{\circ} \mathrm{C}$ and the largest in the test at $750^{\circ} \mathrm{C}$ and high current load (Fig. 4). The same trends were found observing the resistances in the impedance spectra (Fig. 5a and d).

The cell voltage degradation during the test at $850^{\circ} \mathrm{C}$ and humid air was rather small (see circle in Fig. 4). The impedance spectra reveal that the main resistance increase occurred on the polarization resistance; here, specifically at frequencies around $3000 \mathrm{~Hz}$, while the serial resistance remained nearly constant over the $1500 \mathrm{~h}$ aging period (see Fig. 5a and e). The frequency region around $3000 \mathrm{~Hz}$ has been assigned to Ni-YSZ charge-transfer reactions for the type of cells and conditions in this study. ${ }^{10}$ In other words, the cell voltage degradation observed at $850^{\circ} \mathrm{C}$ seems to be mainly related to the anode rather than a consequence of humidifying the cathode air.

During the test at $800^{\circ} \mathrm{C}$, higher current load, and humidified air, the cell voltage degradation was more significant (see square in Fig. 4). In this test, both the polarization and serial resistances increased simultaneously (see Fig. $5 b$ and f). The main changes regarding the polarization resistance occurred around $2000 \mathrm{~Hz}$ and are thus still in relation to anode processes. However, the increase in the serial resistance already points to an additional degradation mechanism.

In both tests at $750{ }^{\circ} \mathrm{C}$ and humidified air at the cathode, significant cell voltage degradation rates were observed (see Fig. 4, triangles at high cell polarization). In both the intermediate $\left(0.41 \mathrm{~A} / \mathrm{cm}^{2}\right)$ and high $\left(0.75 \mathrm{~A} / \mathrm{cm}^{2}\right)$ current loads, the same trends regarding the impedance were observed. Serial and polarization resistances increased simultaneously (see Fig. $5 \mathrm{c}$ and d). Mainly the frequency region around $20-40 \mathrm{kHz}$ was affected, i.e., cathoderelated processes, most probably transport/transfer of oxide ions at the LSM/YSZ interface and through the YSZ in this composite ${ }^{10}$ (see Fig. $5 \mathrm{~g}$ and $\mathrm{h}$ ).

Thus, the same main effects of humidity on impedance were observed during the immediate and long-term periods after the start of the humidification of air, the difference being only the time constants (fast immediate and slow long-term).

In conclusion, not only the immediate cell voltage drop but also the long-term cell voltage degradation during the $\sim 1500 \mathrm{~h}$ period in humid air was reversible, at least to a certain degree. Further, the effect of humidified air on the cell voltage degradation becomes more significant at lower operating temperatures and higher current loads $\left(750^{\circ} \mathrm{C}, 0.75 \mathrm{~A} / \mathrm{cm}^{2}\right)$ and affects cathode processes. 
a)

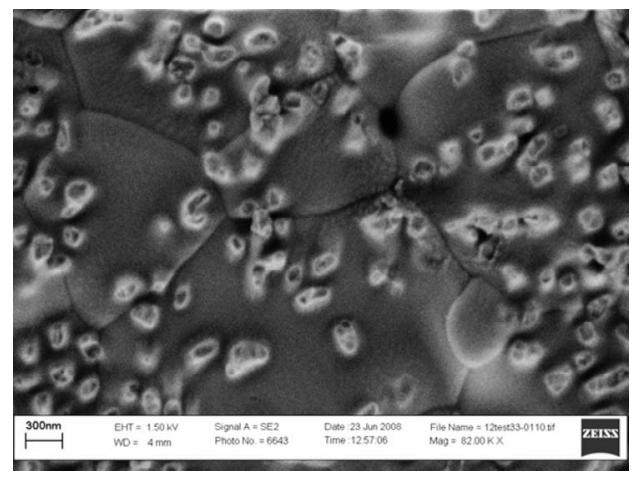

b)

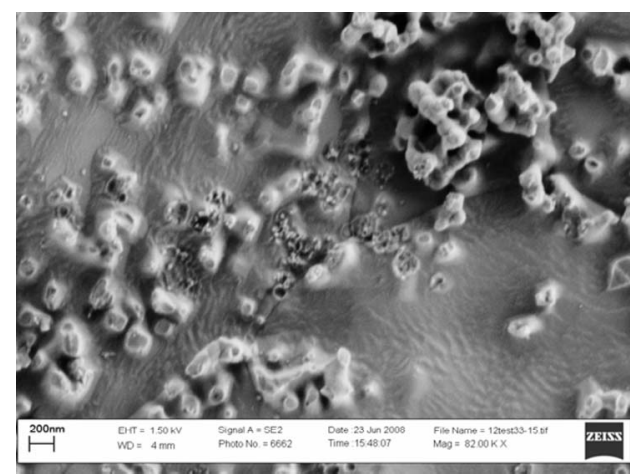

Figure 6. Electrolyte surface after removal of cathode layer: (a) Cell tested in dry air and (b) cell tested in humid air (12test33, see Table I) under a magnification of $82 \mathrm{~K}$
Microstructural analysis. - The cells were studied after completion of the aging tests. As the focus was on the cathode, the same strategy as in a previous study ${ }^{11}$ was applied, i.e., the cathode layer was etched away and the remaining electrolyte surface was analyzed. In Fig. 6, the electrolyte surface of a reference cell tested in dry air and that of a cell tested in humid air are shown.

The electrolyte grains are visible, and on top of them the imprints left by the LSM cathode particles (craters). Furthermore, cathode YSZ particles are seen as protrusions. The comparison between the two tested cells reveals significant differences at the cathode/ electrolyte interface due to the humid air conditions. These cells show, for example, extended formation of ripplelike structures, randomly distributed along the cathode/electrolyte interface and, furthermore, a flattening of crater structures representing contact points between the LSM cathode and YSZ electrolyte. Generally, the differences lay in the extent of these features. Although they were the same as observed for cells tested in dried air under harsh operating conditions over $1500 \mathrm{~h}$, i.e., high current density at $750^{\circ} \mathrm{C}$, they were more pronounced when the air had been humidified, in particular, the ripplelike structures.

The aging tests showed a reversible effect of the humidification of air on the cell voltage. Therefore, the significant structure changes observed on the aged cells after test, such as the ripplelike structures, cannot be responsible for the changes observed following the cell voltages and impedance spectra. That also means that the additional (reversible) aging in humid air has another origin.

The lack of significant evidence after the postmortem microstructural analysis demonstrated the need to obtain a more "in situ" picture of the cell under polarization and humid air conditions. To come as close as possible to this situation, a cell was quenched while being exposed to a high degree of humidified air (13\%), i.e., the temperature was decreased and the polarization was maintained as long as possible. ${ }^{3}$ In the subsequent microstructure analysis, it appeared that nanosized impurity particles were concentrated around the interface region and $\mathrm{Si}, \mathrm{Ca}$, and $\mathrm{S}$ were detected in the regions with high concentration of these particles. ${ }^{3}$ The hypothesis was therefore to relate the degradation effect under humid air and polarization at least partly to impurities, which are likely silicate glassy phases. In steam and under polarization, silicate glassy phases in the materials may become more mobile due to decreased viscosity and enhanced wetability. They may change their shape from blocks into thin films affecting a larger area of interface and could segregate around the three-phase boundary points, ${ }^{12}$ thereby decreasing the performance. When the humidity is removed, these impurity phases could return to their original shape and to less detrimental locations. A more quantitative analysis of the sample using SEM/EDS was not possible due to the insufficient resolution. For a better understanding of this issue, a thorough transmission electron microscopy investigation to analyze the interface and the impurities on a nanoscale is an option; however, it is beyond the scope of the current study.

Improved cell.- Despite the difficulties in identifying the specific origin for the immediate and long-term degradation under humidified air conditions by postmortem microstructural analysis, it is known how important specifically the cathode/electrolyte interface is in regard to the degradation of the type of cells used in this study. ${ }^{11}$ It was therefore expected that changes at this interface would also affect the durability behavior in humid air. It was attempted to improve this interface by depositing an LSM/YSZ cathode with smaller and more evenly distributed particles at the interface to decrease the "polarization per LSM particle." In Fig. 7, the electrolyte surface of an optimized cell after the removal of the cathode in comparison to a reference (standard) cell is shown. Two features were improved: the coverage of the surface with cathode particles; void areas as seen in the standard cell are covered with cathode in the improved cell. In addition, the craters appeared smaller, reflecting smaller cathode particles.

In Fig. 8, the results of aging tests on a standard and an improved a)

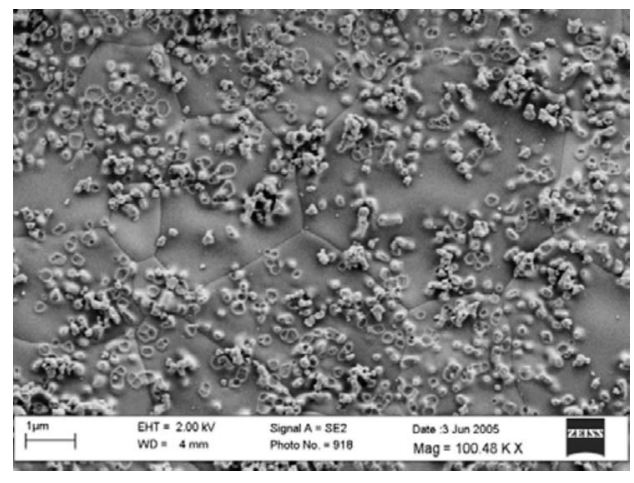

b)

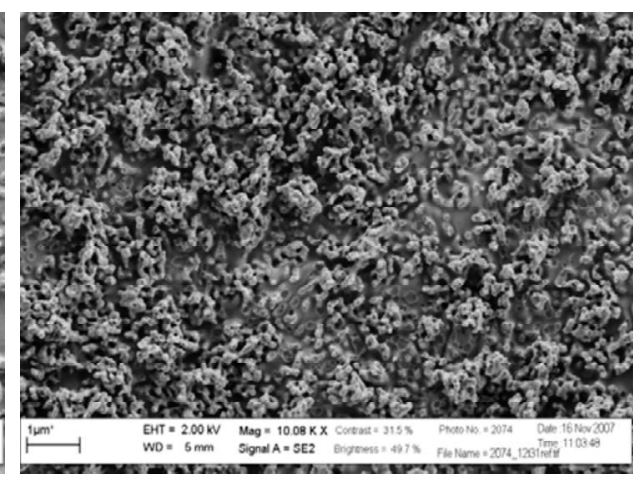

Figure 7. Electrolyte surface after removal of cathode layer: (a) Reference (standard) cell before testing and (b) optimized cell before testing. 


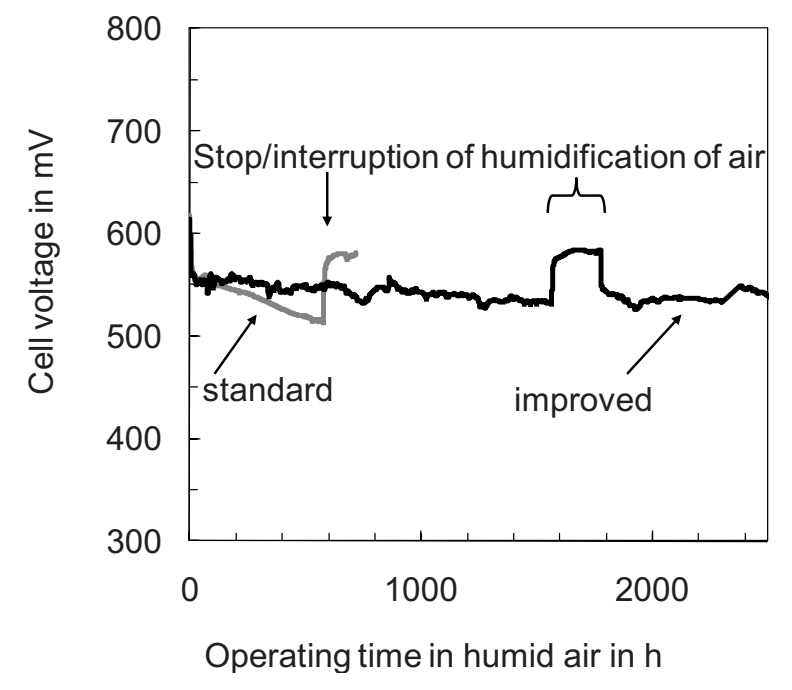

Figure 8. Durability tests in humid air $(\sim 4 \%)$ on a standard and optimized (improved cathode/electrolyte interface) cell at $750{ }^{\circ} \mathrm{C}, 0.5 \mathrm{~A} / \mathrm{cm}^{2}$, synthesis gas fuel with $75 \%$ fuel utilization, $50 \%$ air utilization $(15 \mathrm{~L} / \mathrm{h}$ air) on the standard, and $70 \%(10 \mathrm{~L} / \mathrm{h})$ on the optimized cell. Both cells had been longterm tested before the period under humid air, the standard cell for $1800 \mathrm{~h}$ and the optimized cell for $2300 \mathrm{~h}$. The time scale was normalized to zero at the start of humidification of the air.

cell in humid air at $750^{\circ} \mathrm{C}$ and $0.5 \mathrm{~A} / \mathrm{cm}^{2}$ are shown. The air utilizations were higher than in the previous tests: $50 \%$ on the standard and $70 \%$ on the improved cell. The initial cell voltages were the same for both cells, reflecting similar initial performances. The humidification of air was stopped after $\sim 580 \mathrm{~h}$ for the standard cell; thereafter, the already mentioned immediate recovery of cell voltage occurred. During the test of the optimized cell, the humidity was interrupted for about $200 \mathrm{~h}$ after $1600 \mathrm{~h}$ (see braces in Fig. 8) and stopped after $2500 \mathrm{~h}$ under humidified air conditions.

Indeed, a cell with an LSM/YSZ cathode/YSZ electrolyte interface improved in this way proved to be significantly more durable in humid air at $750^{\circ} \mathrm{C}$ (see Fig. 8). The cell voltage degradation rates when considered after the first $600 \mathrm{~h}$ in humid air for both tests were 84 and $17 \mathrm{mV} / \mathrm{kh}$ for the standard and improved cell, respectively. The improvement factor with regard to humidity tolerance was thus 5. When considering the final $500 \mathrm{~h}$ under humid air, the cell voltage degradation rate of the improved cell was only $1 \mathrm{mV} / \mathrm{kh}$, which makes the improvement factor 100 .

\section{Conclusions}

The durability study of anode-supported cells in humid air showed that these cells can be operated in $\sim 4 \%$ humid air at technologically relevant conditions of more than $1500 \mathrm{~h}$. Humidity has an immediate effect on the cell voltage and a long-term effect, both being reversible to a large extent under the conditions applied in this study and probably related to the segregation of material impurities to the three-phase boundary areas or reversible changes in the chemical composition in humidity and under polarization. Permanent microstructural changes observed, in particular, after aging in humid air (ripplelike structures on the electrolyte surface) do not seem to affect the performance (cell voltage) occurring at high polarization to a larger extent.

The degradation rate of the cell voltage is affected by introducing humidity in air mainly at the lower operating temperatures of $750^{\circ} \mathrm{C}$ and high current densities $\left(0.75 \mathrm{~A} / \mathrm{cm}^{2}\right)$. These are also the conditions that cause degradation in dried air as well and are related to cathode processes on the LSM/YSZ composite cathodes.

Increasing the operating temperature to $850^{\circ} \mathrm{C}$ and decreasing the current density mitigate the effect of humidity in air. Furthermore, the tolerance of cells with LSM-YSZ cathodes can be significantly improved by having an optimal interface between the cathode and electrolyte, i.e., small particles, evenly distributed at the cathode/electrolyte interface. Such improved cells can even operate without significantly increased cell voltage degradation rates at $750^{\circ} \mathrm{C}$ and high current density.

Generally, humidity in air makes SOFCs with an LSM-based cathode worse performing and less durable when the cathode polarization is sufficiently large. This process is largely reversible when removing the humidity from air. The negative trend can be counteracted by decreasing the (local) cathode polarization, for example, by improving the cathode/electrolyte interface structure, by increasing the operating temperature and thereby decreasing the cathode polarization, or by using other cathode materials.

\section{Acknowledgments}

The authors are very thankful to M. Davodi, H. Henriksen, and O. Hansen for the technical assistance in the testing of cells. The financial support from energinet.dk (1-0065) is gratefully acknowledged.

\section{Ris $\phi$ DTU assisted in meeting the publication costs of this article.}

\section{References}

1. N. Sakai, K. Yamaji, T. Horita, Y. Ping Xiong, H. Kishimoto, and H. Yokogawa, J. Electrochem. Soc., 150, A689 (2003).

2. S. Hye Kim, T. Ohshima, Y. Shiratori, K. Itoh, and K. Sasaki, Mater. Res. Soc Symp. Proc., 1041, 1041-R03-10 (2008).

3. J. Nielsen, A. Hagen, and Y. L. Liu, Solid State Ionics, 181, 517 (2010).

4. C. Gindorf, L. Singheiser, and K. Hilpert, J. Phys. Chem. Solids, 66, 384 (2005)

5. J. Guan, S. Zecevic, Y. Liu, P. Lam, R. Klug, M. Alinger, S. Taylor, B. Ramamurthi, R. Sarrafi-Nour, and S. Renou, ECS Trans., 7(1), 405 (2007).

6. J. J. Bentzen, J. V. T. Høgh, R. Barfod, and A. Hagen, Fuel Cells, 9, 823 (2009).

7. A. Hagen, M. Menon, S. Ramousse, P. H. Larsen, R. Barfod, and P. V. Hendriksen, Fuel Cells, 6, 146 (2006).

8. M. Mogensen and P. V. Hendriksen, in High Temperature Solid Oxide Fuel Cells, Fundamentals, Design, and Applications, Chap. 10, S. C. Singhal and K. Kendall, Editors, Elsevier, New York (2003).

9. A. Hagen, R. Barfod, P. V. Hendriksen, Y.-L. Liu, and S. Ramousse, J. Electrochem. Soc., 153, A1165 (2006).

10. R. Barfod, M. Mogensen, T. Klemens $\emptyset$, A. Hagen, Y.-L. Liu, and P. V. Hendriksen, J. Electrochem. Soc., 154, B371 (2007).

11. A. Hagen, Y. L. Liu, R. Barfod, and P. V. Hendriksen, J. Electrochem. Soc., 155 , B1047 (2008).

12. Y. L. Liu, S. Primdahl, and M. Mogensen, Solid State Ionics, 161, 1 (2003). 